\title{
THE CORRELATION BETWEEN ENERGY, CARBOHYDRATE, FAT AND PROTEIN CONSUMPTION LEVEL WITH DEMENSIA IN ELDERLY
}

\author{
Bekti Krisdyana $^{1 *}$, Diffah Hanim ${ }^{1}$, Sugiarto ${ }^{1,2}$ \\ ${ }^{1}$ Nutrition Major, Postgraduate Program Universitas Sebelas Maret Surakarta, Indonesia \\ ${ }^{2}$ Internal Medicine Major, Faculty of Medicine, Universitas Sebelas Maret Surakarta, Indonesia \\ *E-mail: bektikrisdyana@gmail.com
}

\begin{abstract}
Increasing number of elderly population due to influence of increased life expectancy, has an impact on increasing various health problems that occur due to aging process, one of which is dementia. Dementia is influenced by various factors, one of which is the level of nutrient consumption. The purpose of this study was to examine the relationship between level of energy consumption, carbohydrate, fat and protein with dementia in elderly. The population was elderly ( $>60$ y.o) in Tulungagung Regency. This study was cross sectional study with sampling techniques were used cluster random sampling. Samples in this study was 165 person. Variable analysed used chi square test. There were relationship between age, energy and protein consumption level with dementia in elderly $(\mathrm{p}<0.05)$. Elderly who have dementia majority are over 70 years old $(60.5 \%)$. The majority of elderly with dementia have energy and protein consumption level in low category, that is $48.7 \%$ and $55.3 \%$, respectively. The conclusion is that there were correlation between age, level of energy and protein consumption with the incidence of dementia in elderly.
\end{abstract}

Keywords: Energy, Carbohydrate, Fat, Protein Intake, Dementia, Elderly

\section{INTRODUCTION}

The increase in life expectancy has an impact on the evelation in the number of elderly people (elderly) around the world, including in Indonesia (Kemenkes RI, 2017). This has resulted in epidemiological changes in the health sector, one of which is due to dementia. Dementia is a collection of chronic symptoms caused by decreased brain function resulting in cognitive dysfunction which is characterized by deterioration in language, comprehension, numeracy, memory and social skills (Ide, 2008; Kaplan, 2010; Wysocki et al., 2012). It is estimated that more than 130 million people experience dementia between 2015 and 2050 worldwide (Prince, 2016). Meanwhile, in Indonesia the prevalence of dementia in the elderly is around $5 \%$ of the total elderly and this prevalence increases to $20 \%$ for those aged over 85 years (Anurogo \& Usman, 2014)

The occurrence of dementia will have an impact on the disruption of daily activities and social relations between the elderly and the environment (Boustani \& Richard, 2007). Dementia is even one of the causes of death, which is increasing every year (Connors et al.,
2015). In addition, dementia also causes increased dependence of the elderly on productive age. The Indonsesian Statistical Center Organization report (2018) states that the dependence ratio of the elderly to productive age has increased to $14.49 \%$.

Apart from being a result of the aging process, dementia is influenced by various factors including gender, age and nutrient intake (Richard et al., 2007). Women tend to be more at risk of developing dementia than men (Dunen, 2008). One of the causes is the decrease in estrogen levels in women which is directly proportional to age. The hormone estrogen in women functions to protect areas of the brain, especially in the memory and cognitive sections (Eberling, 2003; Eberling, 2004; Robertson, 2009; Genazzani, 2005; Mott \& Pak, 2013).

As someone gets older, the risk of dementia will increase. After entering the age of 60 years, every 5 years of age, the risk of dementia will increase two fold. Paul et al., (2010) found that increasing age corresponds to a decrease in cognitive function.

Nutritional and dietary factors, such as nutrient intake, are modifiable causes of 
dementia (Alles et al., 2012). Decrease in taste and sensitivity to food taste can affect changes in food intake in the elderly, so that certain nutrients can increase or decrease (Kemenkes RI, 2011). Energy intake and macronutrients (carbohydrates, fats and proteins) affect cognitive function and the occurrence of dementia (Kaplan et al., 2001, Campbell \& Campbell, 2006; Creavin et al., 2012). Consumption of energy, carbohydrates, fats and proteins in a certain amount can improve cognitive performance so that it can prevent dementia. Likewise, the opposite can reduce cognitive function which can lead to dementia (Purnakarya, 2009). Robert et al., (2012) reported that the elderly with a percentage of meeting energy needs of $63 \%$ from carbohydrates, $16 \%$ from protein and $25 \%$ from fat have a higher risk of developing dementia compared to elderly people whose energy needs are $41 \%$ from carbohydrates, $20 \%$ of protein and $37 \%$ from fat.

This research is necessary because research on the relationship between the level of energy, carbohydrate, fat and protein consumption with dementia is still limited and shows varying results. Most studies on dementia in the elderly are carried out in social institutions, whereas this study takes place at the community level with locations taken randomly, so that it can provide a better picture of the incidence of dementia and the factors that influence it globally. The purpose of this study was to examine the correlation between gender, age, level of energy, carbohydrate, fat and protein consumption with the incidence of dementia in the elderly in the Tulungagung district.

\section{METHODS}

This research is an analytic observational study with a cross sectional design that takes place in Tulungagung Regency, East Java Province from December 2019 to January 2020. The research location was chosen because Tulungagung Regency has an elderly prevalence (15.25\%) above East Java Province (12.92\%) (BPS, 2017). The dependency ratio of the elderly in Tulungagung Regency is $23.86 \%$. This figure is above the national ratio $(14.49 \%)$ and East Java Province (19.68\%) (BPS, 2017). Information worthy of ethics was obtained from the Health Research
Ethics Commission of Sebelas Maret University (No. 364 / UN27.06 / KEPK / EC / 2019).

The population in this study were people in Tulungagung District who were $>60$ years old. Subjects were taken based on the statement of Santoso (2011), if a study has more than 3 indicators, then the number of $100-150$ subjects is considered sufficient, then added the lost of follow-up from the number of subjects is $10 \%$, so that the total subject becomes 165 subjects. The technique of taking the subject is using the cluster random sampling technique. Public Health Center (PUSKESMAS) in the Tulungagung District area were randomly selected to be the research locations. Tulungagung district has 32 health centers. Ten health centers were taken randomly. From each Puskesmas, Integrated Health Posts (Posyandu) were selected randomly. Then, as much as 165 elderly according to the inclusion and exclusion criteria were chosen randomly. The interview and measurement process was carried out at the Posyandu by researchers, enumerators and mental health officers.

Subject selection was made based on inclusion and exclusion criteria. The inclusion criteria are elderly people who can carry out daily activities independently, actively carry out health checks, regularly participate in elderly exercise, are able to read, write, hear and see well. The exclusion criteria used were elderly people with a history of disease (heart problems, stroke, diabetes and head trauma) and living in nursing homes. Willingness to be a respondent in this study was proven by signing the consent form.

The consumption level data was obtained by interview using a questionnaire, consisting of a 1x24 hour food recall questionnaire, a Mini Mental State Exam / MMSE questionnaire, and a questionnaire on subject characteristics. The $1 \times 24$ hour food recall questionnaire interview used the food model tool. The results of the food recall interview were analyzed electronically to determine the level of energy, carbohydrate, fat and protein consumption. The level of consumption in this case is the intake of energy, carbohydrates, fat and protein of the respondent. The results of the calculation of the consumption level are compared with the Nutrition Adequacy Rate (RDA) for the elderly and multiplied by $100 \%$, then classified 
into more (intake $\geq 120 \% \mathrm{RDA}$ ), normal (intake $90 \%-119 \%$ RDA) and less (intake $<90 \%$ RDA).

Dementia data were obtained by interview using the Mini Mental State Exam / MMSE questionnaire and the results were categorized into normal (cognitive function results 24-30), mild dementia (cognitive function results 19-23), moderate dementia (cognitive function results 1018) and dementia. weight (cognitive function result $<9)$. Gender and age data were obtained through interviews using a questionnaire.

The study of the research results was analyzed descriptively by calculating the frequency distribution of the research results. In addition, a Chi Square test was performed to see the relationship between the independent and dependent variables. Statistical tests were performed using the IBM SPSS statistic 21 program.

\section{RESULTS AND DISCUSSION}

From table 1, it can be seen that the majority of respondents in this study were women (59.4\%) and as many as $50.9 \%$ of respondents were $60-69$ years old. Respondents' energy intake was in the normal category at $40.6 \%$. As many as $44.2 \%$ of respondents had carbohydrate intake in the normal category. Meanwhile, most respondents had low levels of fat and protein intake, respectively $44.2 \%$ and $44.8 \%$. Most of the respondents' dementia status was in the normal category $(53.9 \%)$. Based on the results of this study, data on the prevalence of dementia in the elderly in the Tulungagung District was obtained by $46.1 \%$.

The age range of respondents based on Table 2 weres 61 to 83 years old, with an average age of the respondents being 71 years old. The respondents' average energy intake was 1444.6 Kcal, while the average carbohydrate intake was $221.9 \mathrm{~g}$. The average fat intake of the respondents was $39.6 \mathrm{~g}$ and the average protein intake was 50.2 grams. When compared with the RDA, the average adequacy of energy, carbohydrates, fat and protein of respondents was $86.18 \pm 16.75 \%$, $88.36 \pm 20.11 \%, 80.62 \pm 31.61 \%$ and respectively. $82.89 \pm 21.64 \%$. Daily intake of carbohydrates, fats and protein can affect cognitive function. Elderly (70-89 years) who consume 232 grams of
Tabel 1. Distribution of Gender, Age, Energy Intake, Carbohydrates, Fat, Protein and Dementia in the Elderly in Tulungagung District in 2020

\begin{tabular}{|c|c|c|}
\hline \multirow{2}{*}{ Variable } & \multicolumn{2}{|c|}{ Total } \\
\hline & $\mathbf{n}$ & $\%$ \\
\hline \multicolumn{3}{|l|}{ Gender } \\
\hline Male & 67 & 40.6 \\
\hline Female & 98 & 59.4 \\
\hline \multicolumn{3}{|l|}{ Age } \\
\hline 60-69 у.о & 84 & 50.9 \\
\hline $70-79$ у.о & 50 & 30.3 \\
\hline$\geq 80$ y.o & 31 & 18.8 \\
\hline \multicolumn{3}{|l|}{ Energy intake } \\
\hline Excessive & 36 & 21.8 \\
\hline Normal & 67 & 40.6 \\
\hline Inadequate & 62 & 37.6 \\
\hline \multicolumn{3}{|l|}{ Carbohydrate intake } \\
\hline Excessive & 33 & 20.0 \\
\hline Normal & 73 & 44.2 \\
\hline Inadequate & 59 & 35.8 \\
\hline \multicolumn{3}{|l|}{ Fat intake } \\
\hline Excessive & 39 & 23.6 \\
\hline Normal & 53 & 32.1 \\
\hline Inadequate & 73 & 44.2 \\
\hline \multicolumn{3}{|l|}{ Protein intake } \\
\hline Excessive & 30 & 18.2 \\
\hline Normal & 61 & 37.0 \\
\hline Inadequate & 74 & 44.8 \\
\hline \multicolumn{3}{|l|}{ Dementia } \\
\hline Normal & 89 & 53.9 \\
\hline Mild Dementia & 28 & 17.0 \\
\hline Moderate Dementia & 27 & 16.4 \\
\hline Severe Dementia & 21 & 12.7 \\
\hline
\end{tabular}

Tabel 2. Average Age, Energy, Carbohydrate, Fat and Protein Intake of the Elderly in Tulungagung Regency in 2020

\begin{tabular}{lrrr}
\hline \multicolumn{1}{c}{ Variable } & Min & Maks & Mean \\
\hline Age (years old) & \multicolumn{1}{c}{61} & \multicolumn{1}{c}{83} & \multicolumn{1}{c}{71} \\
Energy intake (Kcal) & 745.1 & 1911.6 & 1444.6 \\
Carbohydrate intake (g) & 112.1 & 347.7 & 221.9 \\
Fat intake (g) & 6.1 & 75.3 & 39.6 \\
Protein intake (g) & 22.1 & 80.2 & 50.2 \\
\hline
\end{tabular}

carbohydrates per day, 78 grams of protein per day, and 61 grams of fat per day have normal cognitive function and do not experience dementia (Roberts et al., 2012).

Based on Table 3, most of the respondents who did not experience dementia were female respondents (64.0\%). However, more than 50\% of respondents who experienced moderate and 
severe dementia were female respondents. The majority of people with dementia are women, namely $61 \%$ of the total dementia sufferers and the rest are men (Alzheimer's Disease International, $2015 b$ ). This condition occurs as a result of the influence of hormones, where the female hormone estrogen decreases which is proportional to age. Meanwhile, one of the functions of the hormone estrogen is to protect areas of the brain, especially in the memory and cognitive areas (Eberling, 2003; Eberling, 2004; Robertson, 2009; Genazzani, 2005; Mott \& Pak, 2013; Pike, 2017). This is also due to differences in neurophysiological conditions and due to differences in lifestyles between men and women (Moser \& Pike 2016; Pike, 2017). Lifestyle factors such as education, stress and physical activity affect the incidence of dementia in men and women ( $\mathrm{Zu}$ et al., 2015). Research by Mulyani et al., (2017) shows that there are differences in physical activity in men and women related to the occurrence of dementia. This is inversely proportional to the results of this study, namely there is no relationship between gender and the incidence of dementia in the elderly $(\mathrm{p}=$ 0.024).

Age is related to the incidence of dementia in the elderly, where the risk of dementia will increase with increasing age (Gibbons et al., 2014). Most of the incidence of dementia occurs when someone is $>60$ years old and about $32 \%$ occurs at the age above 85 years (Prince et al., 2016). Based on the results of the Chi-square test, it is known that there is a relationship between age and the incidence of dementia $(p=0.014)$. This condition is in accordance with the results of research by Paul et al., (2010) which found that increasing age is in line with a decrease in a person's cognitive function. Research in Austria has also shown a decline in mental and cognitive abilities associated with increasing age (Freidl et al., 1996).

Decrease in energy and nutrient needs occurs in line with increasing age (Fatmah, 2010). Energy, carbohydrate, fat and protein intake are associated with the incidence of dementia (Ortega, 1997; Kaplan et al., 2001; Robert et al., 2012; Dieng et al., 2018). Table 3 shows that elderly with

Tabel 3. Relationship of Subject Characteristics, Energy Intake, Carbohydrates, Fat and Protein with Dementia in the Elderly in Tulungagung Regency in 2020

\begin{tabular}{|c|c|c|c|c|c|c|c|c|c|}
\hline \multirow[t]{2}{*}{ Variable } & \multicolumn{2}{|c|}{ Normal } & \multicolumn{2}{|c|}{ Mild Demensia } & \multicolumn{2}{|c|}{$\begin{array}{l}\text { Moderate } \\
\text { Demensia }\end{array}$} & \multicolumn{2}{|c|}{ Severe Demensia } & \multirow[t]{2}{*}{ p-value } \\
\hline & $\mathbf{n}$ & $\%$ & $\mathbf{n}$ & $\%$ & $\mathbf{n}$ & $\%$ & $\mathbf{n}$ & $\%$ & \\
\hline \multicolumn{10}{|l|}{ Gender } \\
\hline Male & 32 & 36.0 & 15 & 53.6 & 11 & 40.7 & 9 & 42.9 & \multirow{2}{*}{0.424} \\
\hline Female & 57 & 64.0 & 13 & 46.4 & 16 & 59.3 & 12 & 57.1 & \\
\hline \multicolumn{10}{|l|}{ Age } \\
\hline $60-69$ у.о & 54 & 60.7 & 11 & 39.3 & 14 & 51.9 & 5 & 23.8 & \multirow{3}{*}{$0.014^{*}$} \\
\hline $70-79$ у.о & 23 & 25.8 & 13 & 46.4 & 6 & 22.2 & 8 & 38.1 & \\
\hline$\geq 80$ y.o & 12 & 13.5 & 4 & 14.3 & 7 & 25.9 & 8 & 38.1 & \\
\hline \multicolumn{10}{|l|}{ Energy intake } \\
\hline Excesive & 18 & 20.2 & 8 & 28.6 & 6 & 22.2 & 4 & 19.0 & \multirow{3}{*}{$0.026^{*}$} \\
\hline Normal & 46 & 51.7 & 10 & 35.7 & 5 & 18.5 & 6 & 28.6 & \\
\hline Inadequate & 25 & 28.1 & 10 & 35.7 & 16 & 59.3 & 11 & 52.4 & \\
\hline \multicolumn{10}{|c|}{ Carbohydrate intake } \\
\hline Excesive & 16 & 18.0 & 7 & 25.0 & 5 & 18.5 & 5 & 23.8 & \multirow{3}{*}{0.620} \\
\hline Normal & 49 & 55.1 & 11 & 39.3 & 8 & 29.6 & 5 & 23.8 & \\
\hline Inadequate & 24 & 27.0 & 10 & 35.7 & 14 & 51.9 & 11 & 52.4 & \\
\hline \multicolumn{10}{|l|}{ Fat intake } \\
\hline Excesive & 18 & 20.2 & 8 & 28.6 & 7 & 25.9 & 6 & 28.6 & \multirow{3}{*}{0.735} \\
\hline Normal & 34 & 38.2 & 7 & 25.0 & 7 & 25.9 & 5 & 23.8 & \\
\hline Inadequate & 37 & 41.6 & 13 & 46.4 & 13 & 48.1 & 10 & 47.6 & \\
\hline \multicolumn{10}{|l|}{ Protein intake } \\
\hline Excesive & 16 & 18.0 & 7 & 25.0 & 5 & 18.5 & 2 & 9.5 & \multirow{3}{*}{$0.018^{*}$} \\
\hline Normal & 41 & 46.1 & 11 & 39.3 & 5 & 18.5 & 4 & 19.0 & \\
\hline Inadequate & 32 & 36.0 & 10 & 35.7 & 17 & 63.0 & 15 & 71.4 & \\
\hline
\end{tabular}

*) statistically significant at $p<\alpha, \alpha=0.05$ 
moderate and severe dementia mostly have low energy intake, $53.9 \%$ and $52.4 \%$, respectively. There was a relationship between energy intake and dementia in the elderly $(\mathrm{p}=0.026)$, low energy intake increased the incidence of dementia in the elderly. This is different from the results of the study by Creavin et al. (2012) where high energy intake in the elderly was associated with an increased risk of cognitive dysfunction.

Meanwhile, the elderly who did not have dementia mostly had normal carbohydrate intake $(55.1 \%)$. In contrast to respondents with moderate and severe dementia, where most of their carbohydrate intake was in the low category. There was no correlation between carbohydrate intake and the incidence of dementia ( $\mathrm{p}=0.62)$, meaning that high or low carbohydrate intake did not affect the incidence of dementia in the elderly. This is different from research by Roberts, et al. (2012) who found that a high percentage of carbohydrate intake in meeting the daily energy needs of the elderly can have an impact on the increased risk of cognitive decline. The higher the percentage of energy fulfillment from carbohydrates, the risk of dementia also increases (Roberts et al., 2012). Increased carbohydrate intake in the elderly is associated with increased consumption of foods with a high glycemic index. Glucose is the main source of energy needed for metabolic activities in the brain and administration of glucose can help improve cognitive performance (Bourre, 2006). However, excessive consumption of carbohydrates and simple sugars in old age can interfere with glucose metabolism and insulin performance (Witte et al., 2009; Malik et al., 2010; J et al., 2009). High insulin levels can interfere with a person's cognitive abilities (Stolk et al., 1997).

Respondents who did not experience dementia or those who have dementia, mostly have less fat intake. Fat intake was not associated with the incidence of dementia $(p=0.735)$, which means that the adequacy of fat consumption did not affect dementia in the elderly. High fat deposits in the human body can result in insulin resistance which affects cognitive performance (Perkeni, 2015; Stok et al., 1997). Research by Nagai et al. (2019) found that intake of high-fat foods can reduce cognitive function and hippocampal neurogenesis in mice. This suggests that consumption of fatty foods can adversely affect cognitive abilities and accelerate the onset of dementia.

Protein intake was associated with dementia $(\mathrm{p}=0.018)$. Respondents with moderate and severe dementia, mostly were in low protein intake. Protein is a nutrient that functions in the formation of neurotransmitters in the brain and nerves (Schelenker \& Long, 2007). It is estimated that $10-25 \%$ of the elderly did not consume protein as recommended and $5-9 \%$ of the elderly only consume protein around $0.66 \mathrm{~g} / \mathrm{kg}$ body weight per day (Volpi et al., 2013). Low protein intake can be associated with a lack of fulfillment of essential amino acid intake needed for neurotransmitter synthesis (Roberts et al., 2012). The occurrence of dementia is related to abnormalities in a number of amino acids that function as neurotransmitters (Ravaglia et al., 2007). Research by Kaplan et al. (2001) reported that consumption of protein sources was significantly associated with improved memory.

\section{CONCLUSION}

There was a positive relationship between age and the incidence of dementia and there was a negative correlation between the level of energy and protein consumption with dementia in the elderly. The older people and the lower the level of energy and protein consumption, the higher the incidence of dementia in the elderly. Further research needs to be done to assess eating patterns using the SQ-FFQ and $2 \times 24$ hour food recall to determine the eating habits of the elderly associated with dementia.

\section{REFERENCES}

Alles, B., Samieri, C., Feart, C., Jutand, M.A., Laurin, D., \& Barberger-Gateau, P. (2012). Dietary patterns: a novel approach to examine the link between nutrition and cognitive function in older individuals. Nutr Res Rev 25: 207-222.

Alzheimer's Disease International. (2015). women and dementia: a global research review. London: Alzheimer's Disease International.

Anurogo, D. \& Usman, F.S. (2014). 45 Penyakit dan gangguan saraf. Yogyakarta : Rapha Publishing. 
Badan Pusat Statistik. (2017). Profil Penduduk Lansia Jawa Timur Tahun 2017. Surabaya: Badan Pusat Statistik Provinsi Jawa Timur.

Badan Pusat Statistik. (2018). Statistik Penduduk Lanjut Usia. Jakarta: Badan Pusat Statistik.

Bourre, J.M. (2006). Effects of nutrients (in food) on the structure and function of the nervous system: update on dietary requirements for brain. Part 2 : macronutrients. J Nutr Health Aging 10:386-399.

Boustani, M. \& Richard, L. (2007). Characteristics assosiated with behavioral symptoms related to demensia in long-term care residents. The Gerontologist 45 (Spesial Issue 1): 56-61.

Boustani, M. \& Richar,d L. (2007). Characteristics assosiated with behavioral symptoms related to demensia in long-term care residents. The Gerontologist 45 (Spesial Issue 1): 56-61.

Campbell, T.C. \& Campbell, I.I.T.M. (2006). China Study. Ballas: Ben Bella Books.

Dunnen. D.W.F., Brouwer, W.H., Bijlard, E., Linschoten, V.K., Eggens, M.E. (2008). No disease in the brain of a 115-year-old woman. Neurobiol Aging 29(8): 1127-1132.

Eberling, J.L., Wu, C., Haan, M.N., Mungas, D., Buonocore, M., \& Jagust, W.J. (2003). Preliminary Evidence that Estrogen Protects against Age-related Hippocampal Atrophy. Neurobiol Aging 24(5): 725-732.

Eberling, J.L., Wu, C., Tong-Turnbeaugh, R., Jagust, W.J. (2004). Estrogen-and-tamoxifen-Associated Effects on Brain Structure and Function. Neuroimage 21(1): 364-371.

Fatmah. (2010). Gizi usia lanjut. Penerbit Buku Erlangga.

Freidl, W., Schmidt, R., Stronegger, W.J., Irmler, A., Reinhart, B., \& Koch, M. (1996). Mini mental state examination: infl uence of sociodemographic, environmental and behavioral factors, and vascular risk factors. $J$ Clin Epidemiol 49(1):73-8.

Genazzani, A.R., Bernardi, F., Pluchino, N., Begliuomini, S., Lenzi, E., Casarosa, E. (2005). Endocrinology of menopausal transition and its brain implications. CNS Spectr. 10(6):449-457.

Gibbons, C., Creese, J., Tran, M., Brazil, K., Chambers, L., Weaver, B. (2014). The psychological and health consequences of caring for a spouse with dementia: a critical comparison of husbands and wives. Journal of Women \& Aging. 26(1): 3-21.
Ide, P. (2008). Seri tune up gaya hidup penghambat alzheimer. Jakarta: PT Elex Media Komputindo.

J, S.R.F., Sa-Roriz, T.M., Rosset, I., Camozzato, A.L,. Santos, A.C., Chaves, M.L., Moriguti, J.C., \& Roriz-Cruz, M. (2009). (Pre)diabetes, brain aging, and cognition. Biochim Biophys Acta 1792:432-443.

Kaplan, H.I. \& Sadock, B.J. (2010). Sinopsis Psikiatri : Ilmu Pengetahuan Perilaku Psikiatri Klinis. Jilid Satu. Editor: Dr. I Made Wiguna. Jakarta: Bina Rupa Aksara.

Kaplan, R.J., Greenwood, C.E., Winocur, G., \& Wolever, T.M.S. (2001). Dietary protein, carbohydrat, and fat enhance memory performanceinthe healthy elderly. Am J Clin Nutr 74: 687-693.

Kementerian Kesehatan RI. (2011). Buku pedoman pelayanan gizi lanjut usia. Jakarta: Direktorat Jenderal Bina Gizi dan Kesehatan Ibu dan Anak.

Kementerian Kesehatan RI. (2017). Analisis Lansia di Indonesia. Jakarta: Pusat Data dan Informasi Kemenkes RI.

Malik, V.S., Popkin, B.M., Bray, G.A., Despres, J.P., Willett, W.C., \& Hu, F.B. (2010). Sugarsweetened beverages and risk of metabolic syndrome and type 2 diabetes: a meta-analysis. Diabetes Care 33:2477-2483.

Moser, V.A. \& Pike, C.J. (2016). Obesity and sex interact in the 693 regulation of alzheimer's disease. Neurosci Biobehav Rev694 67: 102118.

Mott, N.N. \& Pak, T.R. (2013). Estrogen signaling and the aging brain: contextdependent considerations for postmenopausal hormone therapy. ISRN Endocrinol 814690. doi: 10.1155/2013/814690.

Mulyani, A., Lisna, A.F., \& Slamet, R. (2017). Gambaran aktivitas fisik pada lansia demensia di balai perlindungan sosial Tresna Wreda Ciparay Bandung. Jurnal Kepelatihan Olahraga. 9(1): $1-11$.

Nagai, A., Takafumi, M., Shigenobu, M., Kazuo, I., \& Kousaku, O. (2019). Orally administered milk-derived tripeptide improved cognitive decline in mice fed a high-fat diet. FASEB $J$ 33(12):14095-14102.

Ortega, R.M., Requejo, A.M., Andres, P., LlpezSobarer, A.M., Quintas, M.E., \& Rwedondo, M.R. (1997). Dietary intakeand cognitif function in agroup of elderly people. Am J Clin Nutr 66: 803-9. 
Paul, C., Ribeiro, O., \& Santos, P. (2010). Cognitive impairment in old people living in the community. Arch Gerontol Geriatr 51(2):121-4.

Perkeni. (2015). Konsensus pengelolaan dan pencegahan diabetes mellitus tipe 2 di Indonesia 2015. Jakarta: PB Perkeni. Diakses dari pbperkeni.or.id/doc/konsensus.pdf.

Pike, C.J. (2017). Sex and Develompent of Alzeimer's Discase. J Neurosci Res 95: 671680.

Prince, M.J. (2016). World alzheimer report 2016 improving healthcare for people living with dementia: coverage, quality and costs now and in the future. Alzheimer's Disease International: London, England.

Purnakarya, I. (2009). Peran zat gizi makro terhadap kejadian demensia. Jurnal Kesehatan Masyarakat. 3(2): 89-92.

Ravaglia, G., Forti, P., Maioli, F., Bianchi, G., Martelli, M., \& Talerico, T. (2007). Plasma amino acid concentrations in patients with amnestic mild cognitive impairment or Alzheimer disesase. Am J Clin Nutr 80: 483-488.

Richard, J.H., Solane, P.D., Warshaw, G.A., Bernard, M.A., \& Flaherty, E. (2007). Primary care geriatrics-a case based aproach. Elsevier 5: 156-164.

Robertson, D., Craig, M., van Amelsvoort, T., Daly, E., Moore, C., Simmons, A. (2009). Effects of estrogen therapy on age-related differences in gray matter concentration. Climacteric 12(4): 301-309.
Santoso, S. (2011). Structural equation modeling (sem) konsep dan aplikasi dengan AMOS 18. Jakarta, Penerbit PT Elex Media Komputindo.

Schelenker, E.D. \& Long, S. (2007). Williams Essentials of Nutrition \& Diet Therapy Ninth Edition. Mosby Elsevier : Missouri.

Stolk, R.P., Breteler, M.M., Ott, A., Pols, H.A., Lamberts, S.W., Grobbee, D.E., \& Hofman, A. (1997). Insulin and cognitive function in an elderly population. The Rotterdam Study. Diabetes care 20:792-795.

Volpi, E., Campbell, W.W., Dwyer, J.T., Johnson, M.A., Jensen, G.L., Morley, J.E., \& Wolfe, R.R. (2013). Is the optimal level of protein intake for older adults greater than the recommended dietary allowance? J.Gerontol. A Biol. Sci. Med. Sci 68: 677-681.

Witte, A.V., Fobker, M., Gellner, R., Knecht, S., \& Floel, A. (2009). Caloric restriction improves memory in elderly humans. Proc Natl Acad Sci $U S A$ 106:1255-1260.

Wysocki, M., Luo, B.S.X., Scheimedler, J., Dahlman, K., Lesser, G.T., \& Grossman, H. (2012). Hypertension is associated with cognitive decline in elderly people at high risk for dementia. departments of psychiatry and geriatrics and adult development (GTL), Mount Sinai School of Medicine. Am J Geriatr Psychiatry. 20(2): 179-187.

Zu, .W, Lan, T., Hui-Fung, W., Teng, J., \& MengShan, T. (2015). Meta-analysis of modifiable risk factor for alzeimer's diseases. $J$ Neurol Neurosurg Psychiatry. 86(12):1299-306. 